\title{
TO WHOM WILL YE LIKEN ME, AND MAKE ME EQUAL? "* REFORMULATING THE ROLE OF THE COMPARATOR IN THE IDENTIFICATION OF DISCRIMINATION
}

\author{
Asher Gabriel Emanuel ${ }^{*}$
}

\begin{abstract}
The use of comparator groups has to date been central to establishing a breach of s 19 of the New Zealand Bill of Rights Act 1990. The New Zealand courts' approach to the formulation of comparator groups admits a lack of a clear methodology. The author argues that, in the absence of a framework guiding the formulation of the comparator, the methodology permits arbitrary and inconsistent decision-making. The flexibility of the approach risks premature exclusion of claims in reliance on intuitive rather than analytical reasoning, limiting the transformative potential of nondiscrimination provisions and offending against the proper construction of s 19. Of particular concern is the involvement of matters of justification at the comparator stage. The judgments of the High Court and Court of Appeal in B v Chief Executive of the Ministry of Social Development and G B as Executor of the Estate of B of Whangarei v the Chief Executive of the Ministry of Social Development respectively are emblematic of these concerns. Recent developments at the Court of Appeal in Ministry of Health v Atkinson and Child Poverty Action Group Inc v Attorney-General have provided some guidance, but have not gone far enough. The author recommends that the courts defer to the claimant's choice of comparator, and decouple the identification of differential treatment from questions of causation.
\end{abstract}

** Adapted from Isiah 46:5, King James Version.

* Submitted as part of the LLB(Hons) programme at Victoria University of Wellington. Recipient of the Robert Orr McGechan Memorial Prize for the Best Student Work for the Victoria University of Wellington Law Review. I am most grateful for the comments and patience of my supervisor Dr Petra Butler. 


\section{INTRODUCTION}

Westen notoriously argued in his article, "The Empty Idea of Equality", that the concept of equality and by extension, principles of non-discrimination, lack moral content: ${ }^{1}$

[C]ategories of morally alike objects do not exist in nature; moral alikeness is established only when people define categories. To say that people are morally alike is therefore to articulate a moral standard of treatment - a standard or rule specifying certain treatment for certain people - by reference to which they are, and thus are to be treated, alike.

That moral alikeness does not exist in nature does not render the causes of equality and nondiscrimination at law meaningless. It does however demand that we pay closer attention to how we construct categories of likeness. Fittingly, Elias CJ for the majority observed in McAlister $v$ Air New Zealand Ltd (McAlister) that, for a claim of discrimination to succeed, "the choice of comparator is often critical". ${ }^{2}$

Comparators are used to identify differential treatment in the first stage of the test for a breach of s $19^{3}$ of the New Zealand Bill of Rights Act 1990 (BORA). ${ }^{4}$ The comparative approach is simple: the characteristics of the claimant $\mathrm{X}$ and the comparator $\mathrm{Y}$ differ only on a prohibited ground of discrimination. Where $\mathrm{X}$ has been treated differently to $\mathrm{Y}$, it can be said that $\mathrm{X}$ has suffered differential treatment on a prohibited ground. Yet what appears to be an intuitive and common-sense approach has proven more erratic.

Following the Court of Appeal's decision in Ministry of Health $v$ Atkinson (Atkinson) ${ }^{5}$ some considered the New Zealand courts to have settled upon an approach to discrimination. ${ }^{6}$ Yet the recent High Court decision $B v$ Chief Executive of the Ministry of Social Development $(B)^{7}$ demonstrates the difficulties encountered in the application of the Atkinson approach. Further, that the High Court's judgment was upheld on appeal in $G$ B as Executor of the Estate of $B$ of Whangarei

1 Peter Westen "The Empty Idea of Equality" (1982) 95 Harv L Rev 537 at 545.

2 McAlister v Air New Zealand Ltd [2009] NZSC 78, [2010] 1 NZLR 153 at [34].

3 Section 19(1) reads: "Everyone has the right to freedom from discrimination on the grounds of discrimination in the Human Rights Act 1993."

4 This article will not address the test for a breach of s 19 beyond the comparator stage. The current position is that a breach of s 19 consists of (i) differential treatment on a prohibited ground (ii) where such gives rise to a material disadvantage. See Ministry of Health $v$ Atkinson [2012] NZCA 184, [2012] 3 NZLR 456 at [136]; Child Poverty Action Group Inc v Attorney-General [2013] NZCA 420, [2013] 3 NZLR 729 at [43].

5 Ministry of Health $v$ Atkinson, above n 4.

6 Vanessa Haggie "Premature Justification: The Place of Comparator Group Analysis in Discrimination Law in Canada and New Zealand" (LLM Research Paper, Victoria University of Wellington, 2012) at 13.

$7 \quad B v$ Chief Executive of the Ministry of Social Development [2012] NZHC 3165. 
$v$ the Chief Executive of the Ministry of Social Development $(G B)^{8}$ reveals the Court of Appeal's approach to s 19 to be inconsistent. The reasoning in $G B$ cannot be reconciled with the approach adopted in Atkinson, as recently affirmed in the Court of Appeal decision Child Poverty Action Group Inc v Attorney-General (CPAG). ${ }^{9}$

In Part II, this article addresses the interrelationship between s 19 and the use of the comparative approach. It concludes that the lack of a framework for the formulation of comparators permits arbitrary and inconsistent decision-making. In particular, potentially viable claims are prematurely excluded where courts intervene in the formulation of the comparator. The approach adopted in Atkinson and affirmed in CPAG goes some way to limiting the opportunity for premature exclusion, but does not go far enough.

Part III will examine the New Zealand courts' use of comparative methodology, and specifically the approach to formulating comparators. Particular attention will be paid to $B .{ }^{10}$ The formulation of the comparator in that case resulted in the premature exclusion of a claim, and is emblematic of the way in which the use of comparators can limit the scope of non-discrimination provisions.

Substantive recommendations will be explored in Part IV. Departure from reliance upon the comparator as the exclusive means for the identification of differential treatment is desirable. In any event a firm bedrock of principle must underpin the methodology. The author proposes that the choice of the comparator should be the prerogative of the claimant, and that the question of differential treatment should be distinct from questions of causation.

\section{LIMITATIONS OF COMPARATOR REASONING A The Proper Construction of Section 19}

The operation of state necessitates differential treatment. ${ }^{11}$ But s 19 represents a commitment on the part of the state to refrain from differentiating between persons on a limited number of grounds unless such is demonstrably justifiable in a free and democratic society. ${ }^{12}$ This approach to s $19-$

$8 G B$ as Executor of the Estate of $B$ of Whangarei $v$ the Chief Executive of the Ministry of Social Development [2013] NZCA 410, [2013] NZAR 1309.

9 Child Poverty Action Group Inc v Attorney-General, above n 4.

10 This article is based on a critique of $B v$ Chief Executive of the Ministry of Social Development, above $n 7$. Shortly before and after submission respectively, the Court of Appeal handed down the judgments in Child Poverty Action Group Inc $v$ Attorney-General, above $\mathrm{n} 4$, and $G$ B as Executor of the Estate of $B$ of Whangarei $v$ the Chief Executive of the Ministry of Social Development, above $\mathrm{n}$ 8. These judgments have been considered where relevant.

11 Child Poverty Action Group Inc v Attorney-General, above n 4, at [51].

12 Section 5 of the New Zealand Bill of Rights Act 1990 reads: "Subject to section 4, the rights and freedoms contained in this Bill of Rights may be subject only to such reasonable limits prescribed by law as can be demonstrably justified in a free and democratic society." 
where identification and justification of discrimination are discrete enquiries - could be described as the neutral interpretation insofar as it involves reading "discrimination" as being disadvantageous differential treatment on a prohibited ground, rather than something unjustifiable or invidious. ${ }^{13}$

The neutral interpretation was adopted in Atkinson, where it was held that s 19 would be breached if the claimant is treated differently on a prohibited ground resulting in a material disadvantage. ${ }^{14}$ The Court of Appeal has acknowledged that the doctrinally correct approach is to allow BORA rights to bear a wide meaning, conditioned by justifiable limits permissible by dint of $\mathrm{s}$ 5 - only where an inconsistency with a BORA right is identified does s 5 come to bear on the issue. ${ }^{15}$ The interpretation of $\mathrm{s} 19$ need not then accommodate matters of justification: the presence of $\mathrm{s} 5$ as a broad catch-all justification provision provides the alleged discriminator an opportunity to justify the impugned actions. ${ }^{16}$

This means that matters of justification are not relevant to the identification of differential treatment. Indeed, the Court of Appeal noted the undesirability of "justification creep" whereby matters properly addressed by s 5 were imported into the s 19 enquiry. ${ }^{17}$ This position was reaffirmed in CPAG. ${ }^{18}$ Similarly, concerning the Employment Relations Act 2000 (ERA), Elias CJ for the majority noted in McAlister that a comparison that took on the work of justification would leave "no work" for the exception provisions. ${ }^{19}$

The division between identifying and justifying discrimination creates valuable safeguards. Treating the enquiries as separate ensures the fair allocation of burdens of proof and demands that possibly discriminatory actions are subject to an appropriate level of scrutiny. Where the two enquiries are elided those safeguards are subverted, leading to the possible premature exclusion of what would otherwise be viable claims of discrimination.

13 But see Geoffrey Palmer "A Bill of Rights for New Zealand: A White Paper" (Government Printer, Wellington, 1985) at [10.78] where it was suggested that an "invidious" reading was possible. The author's interpretation is not without controversy. Some commentators advocate reading "discrimination" as requiring something further: see Grant Huscroft "Freedom from Discrimination" in Paul Rishworth and others The New Zealand Bill of Rights (Oxford University Press, Auckland, 2003) 366 at 378 . Huscroft's approach was however rejected explicitly by the Court in Ministry of Health v Atkinson, above n 4, at [129].

14 Ministry of Health $v$ Atkinson, above n 4, at [55] and [136].

15 Ministry of Health $v$ Atkinson, above $\mathrm{n}$ 4, at [127]. See also Hansen $v$ R [2007] NZSC 7, [2007] 3 NZLR 1 at [89] per Tipping J, [57] per Blanchard J, [192] per McGrath J and [17] per Elias CJ.

16 Compare s 106 of the Employment Relations Act 2000.

17 Ministry of Health $v$ Atkinson, above n 4, at [132].

18 Child Poverty Action Group Inc v Attorney-General, above n 4, at [65].

19 McAlister v Air New Zealand Ltd, above n 2, at [37]. 
This article contends that an incautious approach to the use of the comparator risks elision of identification and justification of discrimination, and accordingly undermines the proper construction of s 19 .

\section{B Comparative Logic}

The rationale for the comparative approach derives from the apparently common-sense observation that differential treatment can only be ascertained "by comparison with the condition of others"20 - the court should be comparing "apples with apples". ${ }^{21}$ As set out in the example given above, $\mathrm{X}$ and $\mathrm{Y}$ were in all respects alike but for the prohibited ground. Yet no two people are alike in all respects. If the ambition of the claim were refined, it could instead be said that $\mathrm{X}$ and $\mathrm{Y}$ are alike in all material respects. But without some framework for determining what characteristics are "material", the latter formulation is no more helpful.

A "treat likes alike" formulation relies on a series of underlying norms governing who can be considered alike. Westen, commenting on the Equal Protection clause of the Fourteenth Amendment to the United States Constitution, argues that the notion of equality relies on background norms concerning which persons are to be seen as equal. In effect, "the equality formula presupposes anterior constitutional standards for ascertaining 'likeness' and 'unlikeness"'. ${ }^{22}$ In the New Zealand non-discrimination context, the norms to which Westen refers manifest themselves in the rationales that underlie courts' decisions about which comparator is appropriate.

While appearing to be a neutral framework for identifying differential treatment the comparative methodology is in truth a vehicle for these norms. The desire for apparent neutrality is not surprising, Goldberg observes, as "[w]ith their empirical, legalistic cast, comparators strongly suggest that courts' findings of impermissible discrimination are [not] the product of ... an amateur judicial evaluation of social norms". ${ }^{23}$ Yet this appearance of neutrality is itself cause for concern as these norms, to the extent that they operate under the guise of an apparently neutral methodology, remain inarticulate and under-scrutinised.

\section{Premature Justification}

The central concern about the use of the comparator is that it can allow for the premature justification of alleged discrimination without sufficient scrutiny. This occurs where the comparison (a function of s 19) takes on the work of justification (the function of s 5).

20 Andrews v Law Society of British Columbia [1989] 1 SCR 143 at 164 per McIntyre J.

21 Child Poverty Action Group Inc v Attorney-General, above n 4, at [51].

22 Westen, above $\mathrm{n} 1$, at 560 .

23 Suzanne Goldberg "Discrimination by Comparison" (2010) 120 Yale LJ 728 at 802. 


\section{The tendency to import justification}

The incorporation of justification into the comparison is likely to occur in two circumstances. The first is where the court believes that the differential treatment is not deserving of being described as discriminatory. The second is where the court considers there to be a plausible alternative explanation for the differential treatment that suggests it was not on the basis of a prohibited ground. The intrusion of these determinations in the construction of comparators is encouraged by the intrinsic similarity between identifying and justifying differential treatment. As Clayton and Tomlinson observe, "justification of discrimination will often depend on showing that the positions of the two comparators are not, in truth, analogous". ${ }^{24}$ The elision will occur where the comparator is not independent from what Monoghan terms the "discriminatory circumstances"25 the characteristics of the claimant that might well be alternate rationales or justifications for differential treatment.

Consider, for example, a tax-credit conditional upon family status. A claimant may allege that the scheme results in her being treated differently despite being in all material ways alike to a recipient of the credit but for family status. One of the discriminatory circumstances is that they likely have different financial needs by dint of family status. Presumably the legislative purpose of the scheme is to cater to those different needs. The scheme might be defended as having a justifiable goal. The claimant's approach to the case relies on proving similarity with the comparator - they are alike but for family status. The defendant's approach relies on proving the contrary - they are not alike because family status reflects an important difference, that being financial needs. The questions are two sides of the same coin - they each pertain to the comparability or otherwise of the claimant and their proposed comparator. The latter, though, is a matter for justification as it is relevant not to whether there has been differential treatment but rather whether such is justifiable.

If the conceptual boundary between identification and justification of discrimination is less than clear, the similarity of the two questions leads to them being asked simultaneously. The discriminator's reasons for treating the two differently become the court's reasons for denying that the claimant is in fact comparable with the proposed comparator. ${ }^{26}$ Instead of asking whether there has been differential treatment, the question becomes one of whether differential treatment would be justifiable. Where it is thought that differential treatment is justifiable, the likely conclusion is that the two groups are not legitimately comparable: claimant and their comparator are not comparable because they have different financial needs. The discriminatory circumstances (financial need)

24 Richard Clayton and Hugh Tomlinson The Law of Human Rights (2nd ed, Oxford University Press, New York, 2009) vol 1 at [17.138].

25 Karon Monoghan Equality Law (Oxford University Press, New York, 2007) at [6.39].

26 See the criticism of Granovsky v Canada (Minister of Employment and Immigration) 2000 SCC 28, [2000] 1 SCR 703 in Daphne Gilbert and Diana Majury "Critical Comparisons: the Supreme Court of Canada Dooms Section 15" (2006) 24 Windsor YB Access Just 111 at 124. 
become a proxy for the prohibited ground (family status) when they are subsumed into the comparator, shifting focus from the prohibited ground to the legislative purpose or justification. ${ }^{27}$ The comparator takes on the work of s 5 and is no longer a neutral means for identifying differential treatment.

That reasoning, Haggie suggests, "builds in tacit acceptance of a disputed policy at too early a stage and artificially removes the disputed point of discrimination". ${ }^{28}$ Considering the discriminatory circumstances, and by extension justification, at the comparator stage increases the tendency for the construction of a comparator in such a way that denies the very possibility of discrimination.

\section{Sufficient scrutiny}

The tendency to import justification into the s 19 enquiry allows intuitive reactions to supplant sufficient scrutiny. Without any framework that governs who can be compared to whom, the enquiry becomes driven by instinct. The inherent flexibility of the exercise allows it to "slip into arbitrary and inconsistent reasoning" 29 which provides the appearance, but not substance, of analysis. Where a case concerns "discrimination which is regarded as 'normal"' or "acceptable", ${ }^{30}$ the belief that the practice in question does not deserve to be labelled discrimination encourages the formulation of a comparator that incorporates the discriminatory circumstances.

Returning again to the example of tax-credits above, while opinion certainly differs, many would consider such differential treatment "acceptable" in the context of social welfare policy. If that intuition is controlling, the outcome may be that different financial needs becomes accepted as the reason for denying comparability. The determination concerning comparability has then effectively hidden an intuitive determination that the practice is justifiable, and subjects the claimant to the caprice of the fact-finder's beliefs about what is "acceptable". In this vein, the Court of Appeal in Atkinson noted that justification ought be confined to a later enquiry to "avoid decision-making based on instinct rather than analysis". ${ }^{31}$

The concern about the role of intuition is amplified by the way that it replaces further scrutiny. If it is determined that the claimant cannot be compared with the proposed comparator the claim can

27 See $R$ (on the Application of Al Rawi) $v$ Secretary of State for Foreign and Commonwealth Affairs [2006] EWCA Civ 1279, [2007] 2 WLR 1219 at [78].

28 Haggie, above n 6, at 37.

29 Dagmar Schiek, Lisa Waddington and Mark Bell Cases, Materials and Text on National Supranational and International Non-discrimination Law (Hart Publishing, Oxford, 2007) at 201.

30 Aileen McColgan "Cracking the Comparator Problem: Discrimination, 'Equal' Treatment and the Role of Comparisons" (2006) 6 EHRLR 650 at 672.

31 Ministry of Health $v$ Atkinson, above n 4, at [128]. 
proceed no further. In that case the impugned policy or practice will not be subject to scrutiny under s 5 or the relevant provisions for justification or defence. An intuitive judgement that the claimant is not sufficiently alike to the proposed comparator is substituted for thorough scrutiny of the possible justifications under s $5 .{ }^{32}$ Where such is the case, claims Haggie, the premature dismissal without a more thorough examination of the claim "denies the claimant the right to have the disputed policy fully scrutinised for relevance and reasonableness". ${ }^{33}$

Most importantly, discriminatory practices often align with commonly-held beliefs that will prove, in the full measure of time, to have been discriminatory. Such practices might reveal themselves to be unreasonable or irrational when subjected to scrutiny under s 5. But, when the comparator formulation works to legitimise "acceptable" discrimination, the non-discrimination provision is depleted of its capacity to challenge the status quo. ${ }^{34}$

\section{Burdens of proof}

The incorporation of justification at the comparison stage threatens to misallocate the burdens of proof and further disadvantage the claimant. Monoghan notes, in the United Kingdom context, that the stages of a discrimination enquiry must be assessed "discretely, if the burden of proof provisions ... are to be properly respected". ${ }^{35}$ The same issue arises in the New Zealand context if matters of justification are involved at the comparator stage.

Under the ERA the respective burdens of proof are clear from the structure of the legislation. It is the onus of the discriminator to demonstrate that the alleged discrimination falls within the exceptions. ${ }^{36}$ The position of the Supreme Court in McAlister - that the two enquiries were to be distinct lest there be "no work" left for the exception provisions ${ }^{37}$ - reflects the necessity of separating identification and justification of discrimination to maintain the proper allocation of burdens.

32 See Shackell v United Kingdom (45851/99) Section I, ECHR 27 April 2000; Stubbings and others v United Kingdom (1997) 23 EHRR 213 (ECHR); and the criticisms thereof in McColgan, above n 30, at 660.

33 Haggie, above n 6, at 39.

34 See Lord Walker "Treating Like Cases Alike and Unlike Cases Differently: Some Problems of AntiDiscrimination Law" (2010) 16 Canta LR 201 at 211; and Nova Scotia (Attorney General) v Walsh 2002 SCC 83, [2002] 4 SCR 325 at [200] per Gonthier J.

35 Monoghan, above n 25, at [6.48].

36 Human Rights Act 1993, s 92F.

37 McAlister v Air New Zealand Ltd, above n 2, at [37]. 
The position is less clear as regards s 19. Certainly if the claim proceeds to s 5 , the burden will fall upon the discriminator. ${ }^{38}$ But if issues of justification that ought be addressed at $\mathrm{s} 5$ are imported into the comparator exercise, the burden of establishing a breach of s 19 also demands the claimant go some way to disproving the defendant's justification. Similarly, the defendant's onus may be lowered: if issues of justification succeed at the comparator stage, the defendant does not have to later discharge the burden of showing the impugned policy or practice to be compliant with s 5 .

When the defendant's submissions on the issue of comparison are allowed to address issues of justification, the persuasive burden will fall to the claimant. The claimant is compelled to discourage the court from finding the justification relevant to the selection of the comparator. Unless issues of justification are relegated to a later stage, the claimant may need to lead evidence about, for example, the fiscal implications of finding a practice or policy to be discriminatory. Further, s 19 claims are made against the state, and the claimant suffers from a comparative lack of resources. ${ }^{39}$ Schwartz observes that the "claimant usually lacks the resources, access, or knowledge of the government [and] should not be expected to take on the role of the government's mind reader". ${ }^{40}$ This increases the burden on the claimant to establish differential treatment and, in turn, a breach of s 19.

\section{Mirror Comparators}

A mirror comparator will be alike to the claimant in every way but for the prohibited ground. This approach appears desirable as it promises to place the prohibited ground at the centre of the enquiry. The archetypal articulation of the mirror comparison was that of Binnie $\mathrm{J}$ in Hodge $v$ Canada: ${ }^{41}$

The appropriate comparator group is the one which mirrors the characteristics of the claimant (or claimant group) relevant to the benefit or advantage sought except that the statutory definition includes a personal characteristic that is offensive to the Charter or omits a personal characteristic in a way that is offensive to the Charter.

Where the circumstances are simple, the mirror comparator has the advantage of vividly revealing the alleged differential treatment. It has, however, been subject to criticism on several grounds and was abandoned by the Supreme Court of Canada in Withler $v$ Canada (Withler). ${ }^{42}$

38 Andrew Butler and Petra Butler The New Zealand Bill of Rights Act: A Commentary (LexisNexis, Wellington, 2005) at [6.7.1].

39 See Miron v Trudel [1995] 2 SCR 418 at [49] per McLachlin J.

40 Hart Schwartz "Making Sense of Section 15 of the Charter" (2011) 29 NJCL 201 at 224.

41 Hodge v Canada (Minister of Human Resources Development) 2004 SCC 65, [2004] 3 SCR 357 at [23].

42 Withler v Canada (Attorney General) 2011 SCC 12, [2011] 1 SCR 396 at [60]. 
Requiring the claimant to produce the correct comparator from the outset may impose an inappropriate burden by requiring the claimant to predict the court's choice of a comparator. Gilbert and Majury are concerned that "[c]laimants are succumbing to the burden of having to correctly anticipate the court's choice of comparator group and having to prove their case in relation to that group". ${ }^{43}$ The Court in Withler concurred, noting the risk of claims being derailed where a court is willing to substitute a 'more correct' comparator for that which the claimant chose. ${ }^{44}$

For instance, where there are multiple possible causes for an allegedly discriminatory outcome, the cause that differentiates on a prohibited ground may be justified at the comparator stage if the court is of the view that that particular cause was not central. The existence of the other possible causes can be considered reason to deny comparability. The other possible causes then justify the differential treatment at the comparator stage. The Court of Appeal in CPAG was alive to this risk, and noted "the existence of another criterion which may render the person ineligible for assistance does not of itself mean there may not be discrimination on a prohibited ground". ${ }^{45}$

The search is not for a perfect mirror, but one that is a mirror in terms of all "relevant characteristics". Tempering the requirement in this way may still not relieve the claimant of the burden because, as the Court in Withler observes, "[r]ational people may differ on what characteristics are relevant". ${ }^{46}$ Moreover, mirror comparisons are likely to blind the courts to multiple or intersectional discrimination. ${ }^{47}$

The tenor of the Court of Appeal's judgment in CPAG suggests that the Canadian departure from mirror comparison will be followed in New Zealand. ${ }^{48}$ But the idea that the ills of mirror comparison can be avoided by departing from mirror comparisons is, in the author's view, illusory. Mirror comparisons embody a strict requirement of likeness between claimant and comparator. But in making any determination as to whether the claimant's proposed comparator is apt, the court applies some standard for likeness. The various thresholds the courts impose for establishing

43 Gilbert and Majury, above n 26, at 138.

44 At [59].

45 Child Poverty Action Group Inc v Attorney-General, above n 4, at [64].

Withler v Canada (Attorney General), above n 42, at [59].

47 Withler v Canada (Attorney General), above n 42, at [58]. The thorough treatment this issue merits is beyond the scope of this article. See further Gilbert and Majury, above n 26; Sarah Hannet "Equality at the Intersections: The Legislative and Judicial Failure to Tackle Multiple Discrimination" (2003) 23 OJLS 65; Dean Spade "Intersectional Resistance and Law Reform" (2013) 38 Signs 1031; and Nitya Iyer "Categorical Denials: Equality Rights and the Shaping of Social Identity" (1993) 19 Queen's LJ 179.

Child Poverty Action Group Inc v Attorney-General, above n 4, at [49]. 
comparability can then be viewed as occupying a spectrum of formalism, where comparators suffer generally from the risks of mirror comparison. ${ }^{49}$

\section{E Implications}

The recent response by the Court of Appeal in Atkinson and CPAG to the risk of premature justification was to require "matters of justification" to be relegated to the s 5 enquiry. ${ }^{50}$ This demonstrates an awareness of the risks, but is no panacea. Some matters of justification will be easily identifiable and excludable from the s 19 enquiry. For instance, questions of the cost of finding a policy to be discriminatory relate to the utilitarian calculus of $s 5$, and are not relevant to identifying differential treatment. But the similarity between considerations of comparability and justification make it difficult to achieve a clear separation of the enquiries. Determinations of comparability can operate as justification by another name, without clearly offending the judicial direction to exclude matters of justification from the comparison. Mirror comparisons are the most extreme form of this form of justification, but less strict standards required for comparability can have the same effect. The difficulty in excluding matters of justification from the s 19 enquiry and preserving the neutral meaning of discrimination is borne out by the New Zealand jurisprudence.

\section{THE COMPARATIVE APPROACH IN NEW ZEALAND}

This part will examine the development of discrimination jurisprudence in New Zealand. There is a striking vagueness as to precisely what shape the comparator should take. Particular attention will be given to the High Court's decision in $B$ as it is emblematic of the consequences of the approach the appellate courts have adopted toward the role of comparators in discrimination claims.

\section{A Formulation of the Comparator}

Quilter $v$ Attorney-General (Quilter) ${ }^{51}$ was an early application of non-discrimination provisions. It is difficult to discern a majority position from the judgment. ${ }^{52}$ Most relevant to the more recent jurisprudence, Tipping $\mathrm{J}$ adopted a comparative approach, drawing upon a traditional understanding of the meaning of discrimination - in essence, the "difference of treatment in comparable circumstances". ${ }^{53}$ Unfortunately little direction emerges as to the formulation of comparators. Tipping $\mathrm{J}$ suggested that the appropriate comparator would be persons whose

49 See Moore v British Columbia (Education) 2012 SCC 61, [2012] 3 SCR 360 at [30].

50 Ministry of Health v Atkinson, above n 4, at [132]; and Child Poverty Action Group Inc v Attorney-General, above $n$, at [65].

51 Quilter v Attorney-General [1998] 1 NZLR 523 (CA).

52 See Ministry of Health $v$ Atkinson, above n 4, at [127], n 117.

53 At 573 per Tipping J. 
treatment was "logically relevant" to that of the claimant, ${ }^{54}$ but did not venture to give further depth to the notion of "relevance".

In McAlister the Supreme Court adverted to the possibility that, had it been dealing with a case brought under s 19, the Court may have needed to "formulate its own concept of discrimination". ${ }^{55}$ Nonetheless, Elias CJ for the majority ventured to describe the role of a court in formulating a comparator: ${ }^{56}$

The task of a court is to select the comparator which best fits the statutory scheme in relation to the particular ground of discrimination which is in issue, taking full account of all facets of the scheme, including particularly any defences made available to the person against whom discrimination is alleged. A comparator which is appropriate in one setting may produce a completely inapt result in another. It will certainly do so if it effectively deprives part of the statutory scheme of its operation.

The relevance of this direction to the interpretation of s 19 is limited in light of the fact that it concerned a case under the ERA. It has, though, been read more broadly to be of relevance in cases brought under s 19 and so its meaning is of significance.

The observation comprises two operative parts: first, that the comparator should be shaped by the statutory scheme; and, second, that a comparator will be inappropriate if it deprives the statutory scheme of its operation. The import of both parts is contingent on the proper meaning of "statutory scheme". The phrase could have been referring to the statutory scheme under which the claim was brought (the narrow interpretation). Conversely, it could be taken to refer to the impugned scheme where the claim alleges that a statutory scheme is discriminatory (the broad interpretation).

The broad interpretation is undesirable because it allows questions of justification to be imported into the comparator exercise. It lends credence to the intuition that the rationales of the impugned scheme - in effect, the discriminatory circumstances - have a role to play in the formation of the comparator. Moreover, the narrow interpretation ought to be preferred simply because it seems more plausible: all discrimination claims will necessarily be brought under statutory schemes given that non-discrimination provisions are contained in statutes, but not all discrimination claims will allege that a statutory scheme is discriminatory. Further, the reference to defences suggests that the observation concerns the non-discrimination provisions under which discrimination has been alleged. Nonetheless, while courts have generally adopted the narrow interpretation, ${ }^{57}$ in $B$ Collins $\mathrm{J}$ understood the direction to refer to the impugned scheme. ${ }^{58}$ Further,

54 At 573 per Tipping $\mathrm{J}$.

55 McAlister $v$ Air New Zealand Ltd, above n 2, at [33].

56 At [34].

57 Smith v Air New Zealand Ltd [2011] NZCA 20, [2011] 2 NZLR 171 at [31]; Attorney-General on behalf of the Ministry of Health $v$ Idea Services Ltd (in stat man) [2012] NZHC 3229, [2013] 2 NZLR 512 at [136]; 
the broad interpretation was advanced by the Ministry of Health in Atkinson but was neither rejected nor endorsed by the Court. ${ }^{59}$

Aside from the direction to avoid matters of justification during the s 19 enquiry, ${ }^{60}$ the directions that emerge from Atkinson and CPAG are no more clear. The Court in Atkinson framed a breach of s 19 as consisting of "differential treatment or effects as between persons or groups in analogous or comparable situations on the basis of a prohibited ground of discrimination". ${ }^{61}$ The Court did not, though, take the opportunity to further describe the contours of "comparable situations". In the author's view, the judgment provides little more than the direction that the comparator should not be "artificial" or "circular" by incorporating the discriminator's "philosophy". ${ }^{62}$ In CPAG the Court indicated that in selecting the comparator the Court must be looking at the "reality of the situation", 63 yet little more was said as to what that means for the selection of a comparator. No clear method for the formulation of a comparator emerges. The gist of the authorities is that the comparator is very much a creature of context.

\section{B The Difficulty of Excluding Matters of Justification}

Given the lack of authority as to how to formulate a comparator, finding a bright line between determinations as to comparability and matters of justification has proved difficult. In McAlister, the Supreme Court encountered the distinction. McAlister, a pilot, had brought a claim against Air New Zealand alleging discrimination contrary to s 104 of the ERA following his demotion upon attaining the age of 60 years. The United States had adopted a rule prohibiting those aged over 60 from being pilots-in-command. Subsequently Air New Zealand did not allow pilots over the age of 60 to command its 747 aircraft.

The Court of Appeal had found that the appropriate comparator group was not, as the claimant contended, pilots under the age of 60. Instead, it was held that the appropriate comparator group was pilots that for some reason other than age (such as the lack of a visa) were not permitted to fly to the United States. ${ }^{64}$ The Court of Appeal's formulation was a mirror comparator: the only ground of

and Service and Food Workers Union Nga Ringa Tota Inc v Terranova Homes and Care Ltd [2013] NZEmpC 157 at [39].

58 B v Chief Executive of the Ministry of Social Development, above n 7, at [74].

59 Ministry of Health $v$ Atkinson, above n 4, at [70].

60 Ministry of Health v Atkinson, above n 4, at [132]; and Child Poverty Action Group Inc v Attorney-General, above $n$, at [65].

61 Ministry of Health $v$ Atkinson, above n 4, at [55].

62 At [66]-[67].

63 Child Poverty Action Group Inc v Attorney-General, above n 4, at [51].

64 Air New Zealand Ltd v McAlister [2008] NZCA 264, [2008] 3 NZLR 794 at [90]. 
difference was age, after the discriminatory circumstances were incorporated with the comparison. The strict requirement of comparability effected a justification at the stage of comparison.

This formulation was rejected by the Supreme Court. The incorporation into the comparator of justification or defence - here being whether age was a "genuine occupational qualification"65 would "prove too much". ${ }^{6}$ The comparator left "no work to do for ss 30 and 35 [of the HRA], which are an important part of the statutory scheme concerning age discrimination and introduce carefully stated checks and balances". ${ }^{67}$ The Court required that the identification of discrimination and the defence be distinct enquiries. But the Court did not go so far as to identify the broader concern of premature justification that affects comparisons under both the ERA and s 19.

It should be noted that the comparators selected by the Court of Appeal and Supreme Court, while different, both conform with the basic premise of the court making a determination as to comparability. The difference is that the Court of Appeal applied a stricter standard of comparability, in part due to a focus on causation as an important factor for the formulation of the comparator. ${ }^{68}$ The Court of Appeal's approach as it was framed could be said to not formally offend the direction in Atkinson and CPAG to exclude matters of justification from the s 19 enquiry, ${ }^{69}$ though in substance it does.

The Court of Appeal adopted the limited comparator in part because it was thought to provide a better picture of whether the alleged discrimination was on the basis of the prohibited ground - it permitted "a focus on the true role of that factor". ${ }^{70}$ So formally the outcome could be ascribed to a determination that the treatment was not on the basis of a prohibited ground, rather than an incorporation of justification. Justification is, though, its effect. Where the intuition is that there is a plausible alternative explanation for the differential treatment, formulating the comparator to assess whether the treatment was on the basis of a prohibited ground can function as justification.

The involvement of justification at the comparator stage was again at issue in Atkinson. The respondent, the Ministry of Health, argued that the comparator preferred by the High Court was inappropriate as it would prevent the operation of the impugned policy. ${ }^{71}$ Such a comparator would, it was submitted, offend against the McAlister direction that a comparator will be inappropriate

65 Human Rights Act 1993, s 30(1).

66 McAlister $v$ Air New Zealand Ltd, above n 2, at [37].

67 At [37].

68 At [45].

69 Ministry of Health v Atkinson, above n 4, at [132]; and Child Poverty Action Group Inc v Attorney-General, above $n$, at [65].

70 Air New Zealand Ltd v McAlister, above n 64, at [90].

71 Ministry of Health $v$ Atkinson, above n 4, at [70]. 
where it "effectively deprives part of the statutory scheme of its operation". ${ }^{72}$ It was submitted that to avoid depriving the policy of its operation, the comparator should recognise that the familial relationships between the claimants and their disabled children rendered them incomparable with other caregivers. ${ }^{73}$ It appears that the Ministry's strategy was to persuade the Court to accept a comparator narrowly constructed in conformity with the allegedly discriminatory policy to avoid the more thorough scrutiny of a s 5 enquiry.

The Court dismissed the Ministry's comparator broadly for two reasons. Firstly, it was said to reflect an artificial incorporation of the Ministry's philosophy. ${ }^{74}$ But while the Court was alive to the "circularity" of the Ministry's proposed comparator, it failed to establish a principled boundary between the comparator and discriminatory circumstances. The Court rejected the resultant comparator, but did not clearly reject the thinking that underpinned the Ministry's submission.

This failing is evidenced by the Court's adoption of evidential factors as the second ground on which to reject the Ministry's submission. The Court noted that prior payments to individuals in the same class as the claimants had not "brought the system to an end". ${ }^{75}$ This response indicates a lack of conceptual clarity as it contradicts the first ground for rejecting the submission - that the discriminatory circumstances should not intrude upon the comparator. By implication, had the fiscal implications been more grave, the Court may have been willing to find the claimant's comparator inappropriate on those grounds. Entertaining this line of enquiry suggests that the cost of the scheme is a factor relevant to the likenesses between the claimant and the proposed comparator.

This confusion is underscored by the Court's failure to reject explicitly the Ministry's interpretation of McAlister: that a comparator is inappropriate where it deprives the impugned scheme of operation. ${ }^{76}$ Indeed, considering the fiscal consequence of a finding of comparability implicitly endorses that interpretation. That the Court considered what are in fact matters of justification while in the same judgment stating that they were irrelevant to the comparator demonstrates that a bright line between comparability and justification is elusive. Moreover, allowing such evidence to be led in relation to the selection of the comparator risks misallocating the burdens of proof by requiring the claimant to lead evidence on the fiscal implications of their claim, as was the case here. ${ }^{77}$ Had the Ministry's submission been rejected on principled grounds the outcome in $B$ and $G B$ could perhaps have been avoided.

72 McAlister v Air New Zealand Ltd, above n 2, at [34].

73 Ministry of Health $v$ Atkinson, above n 4, at [67].

74 Ministry of Health $v$ Atkinson, above n 4, at [67].

75 At [73].

76 At [70].

77 At [72]. See above at Part II.C.4 - Burdens of proof. 


\section{B v Chief Executive of the Ministry of Social Development}

In $B$ the High Court considered whether asset deprivation regulations concerning gifting to trusts in the context of an application for a residential care subsidy were discriminatory on the ground of family status. Mrs and Mr B had, for some time, each gifted \$27,000 per year to a family trust. Mrs B later moved into a rest home and applied for the residential care subsidy, which is subject to means assessment. At issue was whether the Social Security Act 1964 and relevant regulations required that the means assessment for the subsidy comprise an aggregation of a couple's gifts, or if the gifts of each partner could be considered independently. Counsel for B contended, inter alia, that the aggregation of gifts was inconsistent with her right not to be subject to discrimination on grounds of family status, as defined in s 21(1)(b) of the HRA. ${ }^{78}$ Following the Court of Appeal in Atkinson, Collins J adopted a comparative approach. ${ }^{79}$

The error in the formulation of the comparator began with Collins J's use of an example of the comparative approach, which he considered to be useful as an illustration of "how comparator methodology can on occasions illuminate unjustifiable discrimination". ${ }^{80}$ This description of the usefulness of the methodology claims too much. Comparators can identify differential treatment, but are not apt to the more complicated task of assessing whether such treatment is justifiable.

The example comparator addresses a discriminatory element of the regulations that were not at issue in $B$ - the pre-2007 distinction between couples in same-sex de facto relationships and those in other forms of relationship. The comparator formulated to identify that distinction was then: ${ }^{81}$

(1) Couple A are in a same sex de facto relationship;

(2) Couple B are married, in a civil union or opposite sex de facto relationship;

(3) Couple A and B's circumstances are in all material respects identical. However, Couple A were treated more favourably than Couple B solely because they were in a same sex de facto relationship.

This is a mirror comparator. The only difference between the hypothetical claimants Couple A and the comparator Couple B is the ground of discrimination, here being marital status. Mirror comparators are not per se inappropriate - sometimes the mirror of the claimant makes for an apt comparison, but not because it is a mirror. ${ }^{82}$ The reliance on this example appears to have locked

$78 \quad B v$ Chief Executive of the Ministry of Social Development, above $n$ 7, at [65].

79 At [66].

80 At [68].

81 At [69].

82 See Withler $v$ Canada (Attorney General), above n 42, at [55]; and above at Part II.D - Mirror Comparators. 
the process into a search for a mirror comparison of $B$ : if the example comparator is undisputed and is a mirror of the hypothetical claimant then nothing less will suffice for the actual comparison the claimant seeks.

The problems that begin with the misleading example are exacerbated by subsequent interpretation of the McAlister dicta directing that the ideal comparator is that which "best fits the statutory scheme". ${ }^{83}$ Collins J appears to interpret this as a direction to mould the comparator to the contours of the impugned scheme, rather than the non-discrimination provisions under which the claim has been brought, adopting what was above termed the broad interpretation. ${ }^{84}$

B's proposed comparator (a single person) was rejected on the grounds that such a formulation: ${ }^{85}$

ignores the statutory scheme and purpose of the Act and Regulations which are reflected by the lawmaker's view that couples ... co-mingle their assets and ought be treated as a combined unit rather than two individuals when assessing the nature of the disposed assets.

As such Collins $\mathrm{J}$ concluded that "there is no discrimination because the lawmakers have not failed to treat like cases alike". ${ }^{86}$ The claimant and the comparator are determined to not be sufficiently alike because the rationale underlying the policy is reason to not consider them alike. Entertaining the legislative purpose during the formulation of the comparator leads to the incorporation of justification at the comparator stage. That, as discussed above, Collins $\mathrm{J}$ expects the comparator methodology to comprise both identification and justification ${ }^{87}$ might go some way to explain his conclusion that, in light of the purpose of the Act and regulations, there is no plausible comparator.

Certainly there are situations where a lawmaker's view is patently unreasonable. Returning to Collins J's example comparator, the lawmaker's view that same-sex de facto couples ought to be treated differently would surely not have sufficed as reason to consider them incomparable with couples in other forms of relationship. The controlling difference appears to be that the form of discrimination at issue in $B$ falls within the bounds of differential treatment that is considered "acceptable". The scheme was discriminatory: it did disadvantage Mrs B by differential treatment on grounds of family status. It might however be justifiable discrimination. But the flexibility of the methodology allowed the comparator exercise to serve as cover for the intuitive conclusion that this kind of differential treatment is not deserving of being described as discrimination.

83 McAlister v Air New Zealand Ltd, above n 2, at [34].

84 See above at Part III.A - Formulation of the Comparator.

$85 B v$ Chief Executive of the Ministry of Social Development, above n 7, at [74].

86 At [75].

$87 B v$ Chief Executive of the Ministry of Social Development, above $\mathrm{n}$ 7, at [68]. 
The lawmaker's view may be a sufficient justification if it can sustain scrutiny under s 5 . But the sufficiency of the justification cannot be known in the absence of that scrutiny. Ironically, Collins $\mathrm{J}$ acknowledges that a consideration of s 5 would have been difficult "absent submissions and possibly evidence from the Crown" as to whether the differential treatment was justifiable. ${ }^{88}$ This observation gives credence to the concern that justifications that occur during the comparator exercise are subject to less scrutiny than those that arise under a s 5 enquiry. Indeed, the Ministry did not have to lead any evidence as to the reasonableness or rationality of the differential treatment.

The Court of Appeal upheld the judgment of Collins $\mathrm{J}$ in $G B^{89}$ Responding to the claimant's contention that the appropriate comparator was a single person, the Court of Appeal observed: ${ }^{90}$

Single persons by and large organise their financial affairs on a different basis from couples. Certainly in this case, Mr and Mrs B lived together and set up their family trust together. They appeared to have pooled their assets and financial activities. In that regard, their financial position is different from a single person, and there is no analogy or comparable situation to a single person. We agree with Collins $\mathrm{J}$ that in these circumstances it is artificial to try to compare a single person with couples.

The correct comparator was then "a person who applies for a residential care subsidy who, like the [Bs], is in a long-term relationship with another person, where there are real economic consequences arising from the relationship". ${ }^{91}$ While the Court did not explicitly invoke these reasons as justifications as Collins $\mathrm{J}$ did, they nonetheless marshal a number of reasons for rejecting the proposed comparator that are in effect justifications.

Implicit in the observation that the claimant occupies a different financial position from the proposed comparator is the assumption that distinctions based on financial arrangements are justifiable in this context. Underlying that assumption is another: that couples are so commonly in different financial positions to single persons that the distinction can justifiably form part of the law. Neither assumption was tested. By incorporating matters of justification at the s 19 enquiry the approach in $G B$ is contrary to the direction adopted in both Atkinson and CPAG that such should be confined to s $5 .{ }^{92}$

88 At [76].

$89 G B$ as Executor of the Estate of $B$ of Whangarei $v$ the Chief Executive of the Ministry of Social Development, above n 8.

90 At [39].

91 At [40].

92 Ministry of Health v Atkinson, above n 4, at [132]; and Child Poverty Action Group Inc v Attorney-General, above $n$, at [65]. 


\section{Conclusion}

In the author's view, no clear methodology for the formulation of the comparator emerges from the case law. The various disputes and reasoning as the choice of the comparator indicate that the courts struggle to exclude matters of justification from the comparator stage. Indeed, the decisions in $B$ and $G B$ raise concerns that the directions of the Court of Appeal in Atkinson and CPAG might not prevent the incorporation of justification at the comparator stage. While $B$ was decided before $C P A G$, the direction that matters of justification should not form part of the $\mathrm{s} 19$ enquiry was clear in Atkinson, a judgment that Collins $\mathrm{J}$ relied on in $B .{ }^{93}$ Moreover, the inconsistencies between the Court of Appeal's judgment in $G B$ and its prior directions in Atkinson and CPAG reveal the challenges inherent in comparison. It is no simple task to exclude matters of justification from the comparator. Where the court involves itself in determining whether the claimant and proposed comparator are suitably comparable, intuitions about whether the differential treatment is "acceptable" can result in a denial of comparability that amounts to justification.

\section{REFORMULATING THE COMPARATOR}

This article proposes that a change of approach is necessary to remedy the deficiencies of the comparative approach and give substance to the proper construction of s 19. The courts should remain open to non-comparative means of establishing a breach of s 19. Nonetheless, where a comparator is used, greater conceptual clarity as to the purpose and limitations of the methodology is necessary.

\section{A Complementary Approaches}

While some non-discrimination provisions require a comparative approach, ${ }^{94}$ s 19 simply expresses the principle of non-discrimination. ${ }^{95}$ Accordingly, some authors have suggested that s 19 can bear a non-comparative interpretation. ${ }^{96}$ But, even if discrimination is a fundamentally comparative concept, ${ }^{97}$ it is not necessary that the tools used for the identification of discrimination

$93 B v$ Chief Executive of the Ministry of Social Development, above $\mathrm{n}$ 7, at [66].

94 McAlister v Air New Zealand Ltd, above n 2, at [33]. See s 104 of the Employment Relations Act 2000 ; s 65 of the Human Rights Act 1993; and s 3(1)(b) of the Equal Pay Act 1972.

95 Section 19(1) reads: "Everyone has the right to freedom from discrimination on the grounds of discrimination in the Human Rights Act 1993." Compare s 15 of the Canadian Charter of Rights and Freedoms 1982.

96 Hannah Bain "Turning Equality into Fact: The Status of Comparator Group Analyses in New Zealand Discrimination Law" (LLB (Hons) Dissertation, Victoria University of Wellington, 2010) at 9. But see Quilter v Attorney-General, above n 51, at 573 per Tipping J.

97 Butler and Butler, above n 38, at [17.12.1]. 
be likewise comparative. ${ }^{98}$ Indeed, recent authority increasingly supports the proposition that the comparator is not the sole path to a finding of discrimination under s $19 .{ }^{99}$ In Atkinson the Court of Appeal noted that no one took any issue with the High Court's treatment of the comparator as but a "helpful tool". ${ }^{100}$ Similarly in CPAG the comparator was considered to be "simply a tool in the analysis". 101

What the alternative analysis might be is less clear. In Shamoon $v$ Chief Constable of the Royal Ulster Constabulary Lord Nicholls described the search for a comparator to be potentially "arid and confusing" and better replaced by a causative assessment: the focus ought be on "why" the claimant was treated in the way that she was. ${ }^{102}$ Similarly, Moreau suggests that treatment based on prejudice or stereotyping needs no comparison to be found discriminatory. ${ }^{103}$ But, while apt in some circumstances, such an approach with its focus on intention might fail to capture unwitting or "benign" discrimination. ${ }^{104}$

\section{B A Reformulation}

Even if the comparator is complemented by alternative approaches it remains imperative that the courts develop a comprehensive conception of the role and limitations of the methodology. The case law lacks a consistent expression of what the comparator is supposed to achieve. In $B$, Collins $\mathrm{J}$ expected it to be able to determine whether the differential treatment was justifiable. ${ }^{105}$ The Court in CPAG considered the comparator to be apt "to sort out those distinctions which are made on the basis of a prohibited ground". ${ }^{106}$ These conceptions demand too much.

A good starting point is the observation of Tipping $\mathrm{J}$ in McAlister that the policy of nondiscrimination provisions requires a "purposive and untechnical approach to whether there is ...

98 This article concerns the comparative approach and a proper treatment of non-comparative articulations of discrimination are beyond its scope. See further Sophia Moreau "Equality Rights and the Relevance of Comparator Groups" (2006) 5 JL \& Equality 81; Sophia Moreau "The Wrongs of Unequal Treatment" (2004) 54 UTLJ 291; Schwartz, above n 40; and Goldberg, above n 23.

99 Haggie, above n 6, at 45.

100 Ministry of Health $v$ Atkinson, above n 4, at [60].

101 Child Poverty Action Group Inc v Attorney-General, above n 4, at [51]-[52].

102 Shamoon v Chief Constable of of the Royal Ulster Constabulary [2003] UKHL 11 at [11] per Lord Nicholls.

103 See Moreau "The Wrongs of Unequal Treatment", above n 98, at 303; and Moore v British Columbia (Education), above n 49, at [30].

104 Butler and Butler, above n 38, at [17.14.2].

105 B v Chief Executive of the Ministry of Social Development, above n 7, at [68].

106 Child Poverty Action Group Inc v Attorney-General, above n 4, at [51]. 
prima facie discrimination", ${ }^{107}$ echoing his earlier observations in Quilter. ${ }^{108}$ Similarly useful is the Employment Court's observation in SFWU $v$ Terranova that a comparator is simply a "means to an end". ${ }^{109}$ In the author's view, that end ought to be to frame the s 19 enquiry.

The author proposes the following - a reformulation of the language used in Atkinson ${ }^{110}$ - as an approach to the $\mathrm{s} 19$ analysis:

(a) Has there been differential treatment or effects as between the claimant and their proposed comparator?

(b) Was the differential treatment on the basis of a prohibited ground of discrimination?

(c) Did the treatment cause material disadvantage?

The differences between the author's formulation and that adopted in Atkinson are firstly that differential treatment should be assessed by measure against the claimant's proposed comparator rather than persons that the court considers to be in "analogous or comparable situations". Secondly, whether the treatment was "on the basis of a prohibited ground of discrimination" has been separated from the question of whether there was in fact differential treatment. ${ }^{111}$

\section{Differential treatment}

The author proposes that what has been previously seen to be the first stage ${ }^{112}$ of the s 19 enquiry be understood as in some circumstances comprising two stages. The question of whether there has been differential treatment on a prohibited ground should be divided in two. Differential treatment is the first: has there been differential treatment or effects as between the claimant and their proposed comparator? Here, the court should defer to the claimant's choice of a comparison. The conclusion produced by the comparator can then frame the second question, that being whether the differential treatment was on a prohibited ground. Such a division might appear artificial. That artificiality is useful, though, to properly focus the respective enquiries.

First, deference to the claimant gives substance to the direction to avoid incorporating matters of justification at the comparator stage. ${ }^{113}$ It is not in the claimant's interest to incorporate

107 McAlister v Air New Zealand Ltd, above n 2, at [51].

108 Quilter v Attorney-General, above n 51, at 576.

109 Service and Food Workers Union Nga Ringa Tota Inc v Terranova Homes and Care Ltd, above n 57, at [37].

110 Ministry of Health $v$ Atkinson, above n 4, at [55].

111 At [55].

112 Ministry of Health v Atkinson, above n 4, at [55]; and Butler and Butler, above n 38, at [17.9.40].

113 Ministry of Health v Atkinson, above n 4, at [132]; and Child Poverty Action Group Inc v Attorney-General, above $n 4$, at [65]. 
discriminatory circumstances into the proposed comparator. Intrusions of the limiting norms discussed in this article occur to the extent that the court denies comparability or engages in the task of reformulating the comparator at the behest of the defendant, or intuitions about whether the differential treatment is "acceptable".

Secondly, deferring to the claimant for the selection of the comparator should avoid what are, in the author's view, overly technical concerns about whether a given comparator is acceptable or not. It is not surprising that the courts have gone no further than general nods towards notions of "relevance" and "materiality". Arcane disputes as to which characteristics are material to the comparison serve only to confuse the analysis and obfuscate the question of whether there has been differential treatment. The complexity of the analysis gives rise to the same concerns about the risk of over-burdening potential claimants that was a criticism of mirror comparators. ${ }^{114}$ And, more simply, reframing the claimant's comparator neglects to treat their experience with the respect it deserves.

Thirdly, it resolves the concerns attendant to the use of mirror comparisons. Unlike the suggestion that mirror comparators be abandoned altogether, ${ }^{115}$ deference allows the claimant to adopt a mirror comparison where it is apt and avoid the use of the same where it is not. The harms of mirror comparison are only manifest where the claimant is compelled to find a mirror comparison at pain of having the claim dismissed. In some circumstances mirror comparison will be entirely apt to expose discrimination. ${ }^{116}$

\section{Causation}

Sometimes the question as to whether the differential treatment was on the basis of a prohibited ground will be answered by the comparison, particularly where it is possible to form a mirror comparison. ${ }^{117}$ A mirror comparison produces a very strong inference that the differential treatment was on the proscribed ground and all but obviates the need to consider causation. But where a mirror comparison is not possible, it is necessary to decouple the issue of whether the differential treatment was on the prohibited ground from the issue of whether there was differential treatment at all. ${ }^{118}$ Once the claimant has established differential treatment as regards their proposed

114 Gilbert and Majury, above n 26, at 138.

115 Haggie, above n 6, at 46.

116 Jennifer Koshan and Jonnette Hamilton "Meaningless Mantra: Substantive Equality after Withler" (2011) 16 Rev Const Stud 31 at 53.

117 Child Poverty Action Group Inc v Attorney-General, above n 4, at [51].

118 Compare Child Poverty Action Group Inc v Attorney-General, above n 4, at [51]-[52]. 
comparator, it can then be asked whether the prohibited ground was "material"119 to the differential treatment. $^{120}$

Requiring that questions of causation be addressed separately avoids allowing for intuitive determinations that the alternate explanations for differential treatment prevent comparability. In CPAG it was acknowledged that in cases where multiple criteria operated in concert to produce the allegedly discriminatory outcome, or where effects-based discrimination was at issue, a focus on whether the discrimination was "on the basis of the prohibited ground" may be necessary. ${ }^{121}$ As was the case in McAlister at the Court of Appeal, questions of whether treatment was on the basis of a prohibited ground readily fold back into considerations of whether claimant and comparator are legitimately comparable if the question is asked at the comparator stage.

Such an approach avoids allowing issues of possible multiple causation to deny comparability, as was the case in the Court of Appeal decision in McAlister. Once McAlister had identified the comparator (pilots under the age of 60) the only conclusion as to causation could be that age was material to the outcome. Any questions of whether the differential treatment fell within an exception would have to be left to enquiries under those provisions, rather than being bound up in the comparator analysis. Likewise, this approach would have avoided the outcome in $B$. Framed by the comparison B sought (single persons) the inescapable conclusion is that her family status was a material cause of the differential treatment.

Finally, treating causation as distinct from identifying differential treatment should quell any fears that deference to the claimant in the selection of the comparator might admit unmeritorious claims. The claimant still bears the burden of establishing that the prohibited ground was material to the differential treatment their proposed comparator illustrates.

\section{A Lower Threshold?}

The effect of these recommendations is to lower the de facto threshold to establishing a differential treatment by ensuring a neutral conception of discrimination. Huscroft has misgivings that such an approach allows for any differential treatment accompanied by disadvantage to be described as discrimination, which "may end up trivialising" rather than protecting the right to freedom from discrimination. ${ }^{122}$ Similarly, Haggie expresses concern that the low threshold

119 McAlister v Air New Zealand Ltd, above n 2, at [49] per Tipping J; and Child Poverty Action Group Inc v Attorney-General, above n 4, at [64].

120 See for example the analysis in Attorney-General on behalf of the Ministry of Health $v$ Idea Services Ltd (in stat man), above $n 57$, at [141]-[159].

121 Child Poverty Action Group Inc v Attorney-General, above n 4, at [52]. Compare Attorney-General on behalf of the Ministry of Health $v$ Idea Services Ltd (in stat man), above n 57, at [141] where "on the basis of" was seen as a step subsequent to the identification of the comparator.

122 Huscroft, above n 13, at 376. 
established by the Court of Appeal in Atkinson leads to "uncomfortable questions" about precedent: findings of prima facie discrimination that are justifiable under s 5 might trivialise the idea of discrimination. ${ }^{123}$

Trivialisation might occur where policies or practices that make justifiable distinctions between people were found unlawful. But such a determination would require that a court find them unable to survive scrutiny under s 5 , at which point, the author would suggest, it is no longer "trivial". It should be recalled that a prima facie finding of discrimination is not determinative, and any stigma of a prima facie finding is the unavoidable consequence of a "general rule from which exceptions are allowed". 124

But such a claim might also hide less laudable value-judgements about the appropriate scope of non-discrimination provisions. Haggie's "uncomfortable" example concerns whether a parent who chose to care for a child at home where a daycare funding was available would succeed in establishing a breach of s 19 in a manner similar to the claimants in Atkinson. ${ }^{125}$ Perhaps the "gut reaction" that the effect of such a scheme cannot be "true discrimination"126 should not be trusted. There might be, for example, a legitimate concern that the burden of unpaid family responsibilities disproportionately affects women. The merits of that concern might stand fully revealed if subject to scrutiny under s 5. Relying on a "gut reaction" that such is not the case is somewhat less educative.

Beyond trivialisation, Huscroft also expresses the pragmatic concern that the state will be overburdened by defending claims of discrimination if the threshold is too low. Admittedly, the operation of state requires differential treatment. ${ }^{127}$ Yet the state has also committed itself to refrain from differentiating between persons on limited number of grounds. Where it breaches that commitment it must be called to account for why it has chosen to do so. The unavoidable powerimbalance between the claimant and the state demands that the latter should be willing to bear a larger burden in discrimination proceedings. It is desirable to adopt a "broad approach" to the role of comparators ${ }^{128}$ that requires $\mathrm{s} 5$ to do more work, if that is what is necessary to err on the side of caution and avoid the premature dismissal of potentially legitimate claims. In any event the claimant still bears the burden of establishing a breach of s 19. Most importantly, by requiring the state to justify discrimination where it occurs, the non-discrimination provisions hold it to account in a

123 Haggie, above n 6, at 45.

124 McAlister v Air New Zealand Ltd, above n 2, at [55] per Tipping J.

125 Haggie, above n 6, at 45.

126 At 45.

127 Child Poverty Action Group Inc v Attorney-General, above n 4, at [51].

128 Butler and Butler, above n 38, at [17.12.10]. 
valuable way: it advances that "trend of progressive legal development ... toward the better justification of decisions". 129

\section{CONCLUSION}

Comparators can be a useful tool in assessing whether differential treatment has occurred. Nonetheless, the method tends to encourage justification of differential treatment in absence of sufficient scrutiny. The instructions to exclude matters of justification from the comparator stage adopted in Atkinson and CPAG go some way to limiting the risk of premature justification. But so long as the courts continue to modify or reject claimants' comparators on the grounds that they are insufficiently alike, the risk of excluding otherwise viable claims at an early stage remains.

Deferring to the claimant's choice of comparator avoids allowing matters of justification to prematurely exclude the claim. Separating the question of whether there has been differential treatment from whether that treatment was causatively associated with a prohibited ground prevents the comparison from being confused with issues of causation.

Recalling Westen's observation that to "say that people are morally alike is therefore to articulate a moral standard of treatment", ${ }^{130}$ it must be admitted that intuition and value-judgements will have some role to play in discrimination claims - such allows the provisions to adapt over time. The risk, though, is borne out by our history. The Court of Appeal was apt to note in Atkinson that "[d]istinctions have been drawn in the past which would now be universally regarded with some horror". ${ }^{131}$ When deciding who is comparable, and who might be equal, the courts ought to tread carefully.

129 See Etienne Mureinik "Emerging from Emergency: Human Rights in South Africa" (1994) 92 Mich L Rev 1977 at 1985. See also Butler and Butler, above n 38, at [6.8].

130 Westen, above n 1 , at 545 .

131 Ministry of Health $v$ Atkinson, above n 4, at [131]. 
(2014) 45 VUWLR 